ISSN Cetak 2303-1433

ISSN Online: 2579-7301

\title{
MUSIK MOZART MEMILIKI EKSPRESI BRAIN DERIVERD NEUROTROPHIC FACTOR TERTINGGI PADA SEREBRUM DAN SEREBELLUM RATTUS NORVEGICUS DIBANDINGKAN DENGAN GAMELAN JAWA, SUNDA DAN BALI SELAMA KEHAMILAN
}

\author{
(MOZART MUSIC HAS THE HIGHEST BRAIN DERIVERD NEUROTROPHIC FACTOR \\ EXPRESSION ON THE CEREBRUM AND CEREBELLUM RATTUS NORVEGICUS \\ COMPARED TO JAVANESE, SUNDANESE AND BALINESE GAMELAN DURING \\ PREGNANCY)
}

\author{
Virki Widoyant*, Hermanto Tri J**, Widjiati*** \\ *Magister Ilmu Kesehatan Repoduksi, Fakultas Kedokteran Universitas Airlangga Surabaya, \\ Indonesia, \\ *** Departemen Obstetri dan Ginekologi, Rumah Sakit Dr. Seotomo Surabaya Indonesia, \\ *** Departemen Anatomi Veteriner, Fakultas Kedokteran Hewan Universitas Airlangga Surabaya \\ Indonesia \\ Korespondensi : virkiwidoyanti23@gmail.com
}

\begin{abstract}
ABSTRAK
Pendahulan: Musik dapat memengaruhi sistem saraf parasimpatis atau sistem saraf otomatis, baik secara langsung maupun tidak langsung. Paparan musik Mozarts, gamelan Jawa, Sunda, dan Bali memengaruhi faktor neurotropik yang ada di otak. Metode: Penelitian ini adalah eksperimental laboratorium dengan desain random post-test onlydalam desain kelompok kontrol yang digunakan oleh hewan percobaan Rattus norvegicus sebagai model. Hasil: Ada perbedaan ekspresi brain deriverd neurotrophic factor yang signifikan pada anak Rattus norvegicus antara kelompok dengan $\mathrm{p}=0,018$ (rata-rata 1,60 $\pm 0,42$ untuk kelompok kontrol, 4,00 $\pm 1,85$ untuk kelompok musik mozart, 3,00 \pm 0,96 untuk orang Jawa Kelompok gamelan, 2,48 \pm 0,68 kelompok Gamelan Sunda, dan 2,16 \pm 1,27 pada kelompok Gamelan Bali) juga di otak kecil dengan $\mathrm{p}=$ 0,022 (rata-rata 1, $44 \pm 0,29$ untuk kelompok kontrol, 3,92 \pm 1,81 untuk acara Mozart, $3.04 \pm 0.94$ grup gamelan Jawa, $2.92 \pm 0,41$ grup gamelan Sunda, dan $2.57 \pm 1.053$ grup gamelan Bali). Kesimpulan: Ada perbedaan ekspresi brain deriverd neurotrophic factor pada serebrum dan serebellum Rattus norvegicus antara yang terpapar musik Mozart, gamelan Jawa, Sunda, Bali dan kontrol.
\end{abstract}

Key words : Mozart, Javanese Gamelan, Sundanese Gamelan, Balinese Gamelan, Brain Deriverd Neurotrophic Factor

\section{ABSTRACT}

Introduction: Music can affect the parasympathetic nervous system or the automatic nervous system, both directly and indirectly. The exposure of Mozart's music, Javanese, Sundanese and Balinese gamelan influences neurotropic factors in the brain. Methods: This study was an experimental laboratory with a random post-test design only in the design of the control group used by Rattus norvegicus as a model. Results: There were significant differences in brain deriverd neurotrophic factor expressions in Rattus norvegicus children between groups with $\mathrm{p}=0.018$ (mean $1.60 \pm 0.42$ for the control group, $4.00 \pm 1.85$ for the mozart music group, $3.00 \pm 0.96$ for Javanese gamelan groups, $2.48 \pm 0.68$ Sundanese Gamelan groups, and $2.16 \pm 1.27$ in Balinese Gamelan groups) also in the cerebellum with $\mathrm{p}=0.022$ (average $1,44 \pm 0,29$ for the control group, $3.92 \pm 1.81$ for the Mozart event, $3.04 \pm 0.94$ Javanese gamelan groups, $2.92 \pm 0,41$ Sundanese gamelan groups, and $2.57 \pm 1,053$ Balinese gamelan groups). Discussion: There are differences in the expression of brain derived neurotrophic factors in the cerebrum and Rattus norvegicus cerebellum between those exposed to Mozart music, Javanese, Sundanese, Balinese gamelan and control.

Key words : Mozart, Javanese Gamelan, Sundanese Gamelan, Balinese Gamelan, Brain Deriverd Neurotrophic Factor 
ISSN Cetak 2303-1433

ISSN Online: 2579-7301

\section{PENDAHULUAN}

Kehamilan dan persalinan adalah hal yang ditunggu oleh seorang ibu, terutama primigravida (kehamilan pertama). Sumber Daya Manusia (SDM) yang berkualitas tercermin melalui Indeks Pembangunan Manusia (IPM). Data dari Program Pembangunan Perserikatan Bangsa-Bangsa (2017) menyatakan bahwa HDI Indonesia 2017 adalah 0,563 yang berada di peringkat ke-104 di antara 188 negara di dunia, atau peringkat ke-84 di antara anggota Perhimpunan Bangsa Bangsa Asia Tenggara (ASEAN) (Widyanto, 2013). Janin juga perlu mendapat asupan dari lingkungan ibu. Janin yang terkandung dalam rahim dapat berinteraksi dengan suara dari luar, terutama suara yang ada di lingkungan (Widyanto, 2013).

Otak manusia yang berperan sebagai pusat belajar, memori dan perilaku adalah hipokampus, dimana pematangan dan perkembangan hipokampus terjadi sangat cepat dalam periode yang pendek yaitu dimulai pada akhir kehamilan sampai anak usia 2-3 tahun (Barton, 2014). Stimulasi yang terbukti efektif adalah suara yang menghasilkan kombinasi suara harmonis yang disebut musik. Stimulasi dapat merangsang pembentukan sinapsis atau hubungan antara sel-sel saraf dan menghambat apoptosis atau kematian sel. Apoptosis mengalami puncak pada usia kehamilan sekitar 36-40 minggu (Hermanto, 2013).

BDNF (Brain Derived

Neurotrophic Factor) adalah faktor pertumbuhan saraf utama di otak yang mengatur neurogenesis, pematangan neuron, kelangsungan hidup, dan sinaptik. Meskipun neurogenesis di hippocampus terjadi hingga dewasa, sebagian besar proses neurogenesis terjadi pada periode prenatal dan awal postnatal. Hipokampus akan menyebabkan perubahan morfologis neuron, yaitu bentuk dan ukuran neuron yang lebih kecil, jumlah neuron yang bercabang atau penurunan sinaps (Fretham, 2011).

Musik adalah seni yang paling halus, tetapi memiliki pengaruh besar pada pusat fisik dan jaringan saraf pusat. Musik juga memengaruhi sistem saraf parasimpatis atau sistem saraf otomatis, baik secara langsung maupun tidak langsung (Emy, 2016). Musik klasik Mozart telah diuji sebagai terapi yang aman dan efektif, serta musik gamelan Jawa, Bali dan Sunda tradisional yang memiliki irama teratur dan menenangkan 60-90 per menit mirip dengan musik klasik Mozart (Nike, 2013).

Berdasarkan penjelasan tersebut maka terlihat ada kemiripan antara musik klasik dengan tembang tradisional musik gamelan sehingga menarik untuk diteliti dengan melihat perbedaan ekspresi BDNF Cerebrum dan Cerebelum Rattus norvegicus baru lahir antara yang terpapar musik Mozart, gamelan Jawa, Bali dan Sunda selama masa kebuntingan. Tujuan dari penelitian ini diharapkan bisa menjelaskan upaya peningkatan potensi biopsikososial janin sejak dalam rahim melalui stimulasi musik Mozart, musik tradisional gamelan Jawa, Sunda dan Bali, dimana musik tradisonal gamelan berasal dari budaya Indonesia

\section{BAHAN DAN METODE}

Penelitian ini adalah eksperimental laboratorium dengan desain random posttest only dalam desain kelompok kontrol yang digunakan oleh hewan percobaan Rattus norvegicus sebagai model, yang telah disahkan secara etik sebelum dilakukan di Laboraturium Patologi Fakultas Kedokteran Hewan, Universitas Airlangga Surabaya. Besar sampel dalam penelitian ini adalah lima sampel dalam setiap kelompok yang secara acak dibagi menjadi lima kelompok yaitu kelompok pertama kelompok kontrol, kedua kelompok mozart, ketiga kelompok gamelan Jawa, keempat kelompok gamelan Sunda, kelima kelompok gamelan Bali lima kelompok. Total sampel adalah 30 tikus dan masing-masing kelompok berisi 6. Rattus norvegicus hamil berusia 2-3 bulan dan memenuhi kriteria subjek penelitian adalah berat 110-130 gram, sehat, dan usia kehamilan 19-20 hari. Ibu Rattus norvegicus yang sakit atau meninggal selama perawatan sebelum usia kehamilan 19 hari tidak dapat digunakan untuk percobaan laboratorium. 
ISSN Cetak 2303-1433

ISSN Online: $2579-7301$

Intervensi. Setiap sampel diberi perlakuan sesuai dengan kelompok yang diberikan paparan musik Mozart, paparan gamelan Jawa, paparan gamelan Sunda, paparan Gamelan Bali dan tidak diberi paparan musik dari usia kehamilan 10 sampai 19 hari selama satu jam dalam kotak kedap suara dan gelap seperti malam. Musik diputar dengan menggunakan kotak kedap suara setiap hari selama 1 jam. Waktu paparan selama 9 hari. Menggunakan loudspeaker Sony Model No. SRS- XB30 dan program DSSF3E dengan pengaturan frekuensi menggunakan sound level meter dengan rentan $65 \mathrm{~dB}$.

Outcome. Sampel otak diambil setelah anak Rattus norvegicus dilahirkan oleh sectio caesar pada kehamilan hari ke-19, kemudian otak diambil. Untuk satu preparat mengandung 3 sampel otak faktor neurotropik yang diturunkan dari otak dilakukan dengan menghitung ekspresi di otak janin Rattus norvegicus menggunakan preparat imunohistokimia dan dilihat dengan mikroskop pembesaran 400x. Data dilakukan uji komparatif menggunakan uji ANOVA dan LSD (Least Significant Difference) untuk melihat perbedaan pada masing-masing kelompok.

\section{HASIL}

Rattus norvegicus yang hamil dikelompokkan secara acak dan diambil tiga anak terberat, sedang, dan teringan dari Rattus norvegicus masing-masing sampel anak dikorbankan dan dilakukan dekapitasi dibuat menjadi satu persiapan dengan pewarnaan imunohistokimia. Untuk menguji sebaran data normal menggunakan Uji Shapiro-Wilk.

Table 1 Rata-rata dan simpangan baku berat badan ibu dan anak Rattus norvegicus.

\begin{tabular}{|c|c|c|c|c|c|c|}
\hline \multirow[t]{2}{*}{ Group } & \multicolumn{3}{|c|}{ Induk } & \multicolumn{3}{|c|}{ Anak } \\
\hline & Mean & SD & $\mathrm{p}$ & Mean & SD & $\mathrm{p}$ \\
\hline Control & 119,8 & 3,34 & 0,2 & 0,49 & 0,03 & 0,5 \\
\hline Mozart & 121,8 & 3,49 & 11 & 1,74 & 0,82 & 61 \\
\hline Java & 121,2 & 4,65 & & 1,56 & 0,92 & \\
\hline Sunda & 121,2 & 4,08 & & 1,51 & 0,97 & \\
\hline Bali & 120,2 & 4,14 & & 1,30 & 0,66 & \\
\hline
\end{tabular}

Rata-rata berat badan induk Rattus norvegicus tertinggi adalah kelompok paparan Mozart (121,8 \pm 3,49 gr dan keturunan rata-rata berat badan tertinggi adalah kelompok Mozart (1,74 \pm 0,82 gr).

Tabel 2. Karakteristik BDNF serebrum dan serebellum Ratus norvegicus.

\begin{tabular}{ccccccc}
\hline Group & \multicolumn{3}{c}{ cerebrum } & \multicolumn{3}{c}{ cerebellum } \\
\cline { 2 - 7 } & Mean & SD & $\mathrm{p}$ & Mean & SD & $\mathrm{p}$ \\
\hline Control & 1,60 & 0,42 & 0,468 & 1,44 & 0,29 & 0,777 \\
\hline Mozart & 4,00 & 1,85 & 0,094 & 3,92 & 1,81 & 0,350 \\
\hline Java & 3,00 & 0,96 & 0,335 & 3,04 & 0,94 & 0,202 \\
\hline Sunda & 2,48 & 0,68 & 0,419 & 2,92 & 0,41 & 0,171 \\
\hline Bali & 2,16 & 1,27 & 0,010 & 2,57 & 1,053 & 0,431
\end{tabular}

Ekspresi BDNF kelompok mozart tertinggi adalah Mozart dengan rata-rata pada serebrum $(4,00 \pm 1,85)$ dan serebellum $(3,92$ $\pm 1.81)$.

\section{Analisis hasil serebrum}

Data ekspresi BDNF pada serebrum dan serebellum kelompok Bali tidak berdistribusi normal dengan nilai $(\mathrm{p}<0.05)$. Sedangkan pada kelompok kontrol, musik Mozart, gamelan Jawa, gamelan Sunda berdistribusi normal ( $p>0,05)$. Oleh karena itu, untuk melihat perbedaan pada semua kelompok digunakan Kruskal wallis test

Tabel 3. Kruskal wallis test

\begin{tabular}{|c|c|c|c|}
\hline \multirow{2}{*}{\multicolumn{2}{|c|}{ Ekspresi BDNF }} & & $\mathrm{p}$ \\
\hline & & & 0,018 \\
\hline \multicolumn{4}{|c|}{ Table 4. Mann whitney test results } \\
\hline \begin{tabular}{|l|} 
Cerebrum \\
\end{tabular} & Group & $\mathrm{P}$ & Test \\
\hline \multirow{4}{*}{ Kontrol } & Mozart & 0,022 & independent- $\mathrm{T}$ test \\
\hline & Java & 0,018 & independent- $\mathrm{T}$ test \\
\hline & Sunda & 0,041 & independent- $\mathrm{T}$ test \\
\hline & Bali & 0,527 & mann whitney \\
\hline \multirow{3}{*}{ Mozart } & Java & 0,317 & independent- $\mathrm{T}$ test \\
\hline & Sunda & 0,124 & independent- $\mathrm{T}$ test \\
\hline & Bali & 0,056 & mann whitney \\
\hline \multirow{2}{*}{ Java } & Sunda & 0,356 & independent-T test \\
\hline & Bali & 0,093 & mann whitney \\
\hline Sunda & Bali & 0,248 & mann whitney \\
\hline
\end{tabular}

Table 4. Menunjukkan hasil ekspresi BDNF dengan uji Mann Whitney dan independen T test serebrum anak Rattus norvegicus yang baru lahir di bandingkan dengan semua masing-masing kelompok terdapat perbedaan yang signifikan dengan nilai $\mathrm{p}$ $<0,05$.

\section{Analisis hasil serebellum}

Table 5 Hasil menunjukkan ada perbedaan yang signifikan pada ekspresi BDNF antara semua kelompok $\mathrm{p}=0,022$. 
ISSN Cetak 2303-1433

ISSN Online: 2579-7301

Table 5. Anova test

Ekspresi BDNF

$\mathrm{p}$

0,022

Table 6. Post-Hoc LSD results

\begin{tabular}{ccccc}
\hline Group & \multicolumn{4}{c}{$\mathrm{p}$} \\
\cline { 2 - 5 } & Mozart & Java & Sunda & Bali \\
\hline Control & $0,001^{*}$ & $0,026^{*}$ & $0,038^{*}$ & 0,106 \\
\hline Mozart & & 0,202 & $0,150^{*}$ & $0,057^{*}$ \\
\hline Java & & & 0,859 & 0,489 \\
\hline Sunda & & & & 0,606 \\
\hline
\end{tabular}

Table 6 Hasil menunjukan bahwa ekspresi BDNF anak Rattus norvegicus pada serebelum memiliki perbedaan yang signifikan antara kelompok kontrol dan semua kelompok paparan musik kecuali paparan musik gamelan Bali $(\mathrm{p}=106)$. Kelompok paparan musik Mozart juga memiliki perbedaan yang signifikan dengan semua kelompok.

\section{PEMBAHASAN}

Setiap alat musik akan menghasilkan gelombang suara yang unik dengan karakteristik yang berbeda. Persepsi pendengaran manusia dapat mendeteksi perbedaan antara dua atau lebih gelombang suara musik. Karakteristik suara yang unik dari gelombang dapat ditentukan oleh frekuensi, tingkat tekanan suara, durasi perambatan gelombang suara, dan waktu (Pratomo, 2008). Efek Mozart mengacu pada peningkatan kinerja atau perubahan dalam aktivitas neurofisiologis yang terkait dengan mendengarkan musik Mozart. Efek ini telah terbukti memberikan peningkatan yang konsisten dalam tes ruang IQ spasial. Neurofisiologi otak berubah ketika mendengarkan efek musik Mozart telah diamati menggunakan electroencephalograph (EEG) dan pengukuran yang koheren. Perubahan EEG dan koherensi terutama di wilayah temporal dilaporkan oleh Petsche dan rekannya (Supradewi, 2010).

Dalam studi sensitivitas membran Basilar di dasar chinchilla cochlea pada frekuensi sekitar 500-10.000 Hz dengan suara yang diukur dalam desibel, sensitivitas diperoleh pada frekuensi sekitar $8000 \mathrm{~Hz}$. Frekuensi sekitar $8.000 \mathrm{~Hz}$ sangat berguna untuk mengisi sel di otak. Musik yang kaya akan frekuensi tinggi dan memiliki ritme tinggi yang mirip dengan irama detak jantung janin dan dapat dikaitkan dengan fungsi simulasi dan pemberian energi adalah musik Mozart (de Voigt and Vervoot, 2018). Jadi untuk semua jenis musik yang terpapar telah disesuaikan dengan intensitas $65 \mathrm{db}$ menggunakan sound level meter.

Hasil lain dari penelitian ini adalah ada perbedaan pada ekspresi BDNF serebrum dan serebellum antara subject yang terpapar musik Mozart, gamelan Jawa, Sunda, dan Bali dengan yang tidak terpapar musik. Saat diberikan musik, getaran suara akan memasuki telinga dan ditransmisikan ke cairan di telinga bagian dalam. Gelombang suara akan mengaktifkan area spesifik dari membran basiler sesuai dengan frekuensi getaran. Karakteristik frekuensi terkait dengan tonotomi koklea, yang didefinisikan sebagai frekuensi sensitivitas maksimum (ambang minimum) pada tingkat kebisingan rendah, dengan pemetaan frekuensi yang lebih tinggi menyebabkan pergerakan ke basal spiral koklea dan frekuensi yang lebih rendah menyebabkan perpindahan ke puncak koklea (Shera, 2015 ). Musik gamelan Jawa yang sistemik dalam nada non diatonis (dalam laras slendro dan pelog) yang menggunakan sistem notasi yang indah, warna, suara, ritme yang terdengar serta musik gamelan Jawa tradisional yang memiliki irama teratur dan menenangkan dengan ketukan 60-90 per menit mirip dengan musik klasik Mozart (Sukinah, 2011)

Gamelan Sunda berasal dari Jawa Barat yang cenderung memiliki suara yang lebih lambat, dengan gaya bermain yang tidak cepat. Pandangan orang Jawa tentang kehidupan yang diekspresikan dalam musik gamelan adalah keharmonisan kehidupan fisik dan spiritual, keharmonisan dalam berbicara dan bertindak sehingga tidak memunculkan ekspresi eksplosif. Gamelan Bali mempunyai karakter yang kuat dan yang paling mempunyai cii khas dengam ritme yang cepat, dikarenakan gamelan Bali memiliki sebuah perangkat yang berbentuk Cymbal berukuran kecil disebut dengan Ceng-Ceng hal inilah yang membuat suara gamelan itu terdengan cepat dan berbeda 
ISSN Cetak 2303-1433

ISSN Online: 2579-7301

dengan suara gamelan Jawa dan Sunda. Suara musik gamelan yang berkembang di Jawa sedikit berbeda dengan suara musik gamelan di Bali, dimana suara musik gamelan Jawa dan Sunda memiliki suara dan nada yang lebih lembut (Widhyatama, 2012) Gamelan Jawa, Bali dan Sunda yang memiliki irama teratur dan menenangkan dengan irama 60-90 per menit mirip dengan musik klasik Mozart (Oktavia, 2013). Dimana detaknya sesuai dengan detak jantung ibu. Musik gamelan adalah musik yang menggunakan skala Pelog dan Slendro (laras). Slendro adalah kelompok skala pentatonik (laras) yang biasanya ceria, lincah dan ceria, dan skala Pelog persis sama dengan skala pentatonik utama (5 nada).

Kelompok pemaparan gamelan Jawa dan Sunda memiliki perbedaan ekspresi BDNF pada serebellum dengan kelompok yang tidak terpapar musik tetapi tidak ada perbedaan antara kelompok pemaparan gamelan Bali dan kelompok kontrol. Gamelan Bali memiliki karakter yang kuat dan memiliki karakteristik dengan ritme yang cepat, karena gamelan Bali memiliki perangkat Cymbal kecil yang disebut CengCeng yang membuat suara gamelan cepat dan berbeda dari suara gamelan Jawa. Suara musik gamelan yang berkembang di Jawa sedikit berbeda dari suara musik gamelan di Bali, di mana suara musik gamelan Jawa dan Sunda memiliki suara dan nada yang lebih lembut (Widhyatama, 2012).

Paparan musik Mozart pada serebrum dan serebellum yang lebih tinggi daripada semua kelompok paparan gamelan. Dari hasil penelitian ini ditemukan perbedaan ekspresi BDNF di serebrum dan serebellum antara musik Mozart dan yang terpapar musik gamelan Jawa, gamelan Sunda dan gamelan Bali. Musik yang digunakan dalam penelitian ini telah dianalisis menggunakan perangkat lunak cool edit pro 2.0 didapatkan $8.000 \mathrm{~Hz}$, sementara musik gamelan Jawa, Sunda dan Bali ditemukan berkisar 15.000 Hz. Frekuensi ini lebih tinggi dari musik Mozart. Perbedaan frekuensi ini akan ditangkap secara berbeda dengan koklea, sehingga respons terhadap otak akan berbeda. Penelitian sebelumnya menjelaskan bahwa sensitivitas membran basilar di dasar chonchilla cochlea memperoleh sensitivitas pada frekuensi sekitar $8000 \mathrm{~Hz}$ yang berguna untuk mengisi sel-sel otak (Hermanto, 2017). Musik yang kaya akan frekuensi tinggi dan memiliki ritme tinggi (mirip dengan irama detak jantung janin), yang dapat dihubungkan dengan fungsi stimulasi dan pemberian energi. Gelombang suara akan mengaktifkan area spesifik dari membran basiler sesuai dengan frekuensi getaran. Karakteristik frekuensi terkait dengan tonotomi koklea, yang didefinisikan sebagai frekuensi sensitivitas maksimum (ambang minimum) pada tingkat kebisingan rendah, dengan pemetaan frekuensi yang lebih tinggi menyebabkan pergerakan ke basal spiral koklea dan frekuensi yang lebih rendah menyebabkan perpindahan ke puncak koklea (Shera, 2015 ).

\section{SIMPULAN DAN SARAN}

Musik Mozart menghasilkan ekspresi BDNF di serebrum dan serebellum Ratus norvegicus paling tinggi dibandingkan kelompok yang lain.

\section{DAFTAR PUSTAKA}

Barton, R.A., dan Venditti, C. 2014. Rapid Evolution of the Cerebellum in Humans and Other Great Apes. Current Biology , 24(20):2440-2444.

Campbell, Jane B. Reece \& Lawrence G. Mitchell. 2011. Biology- 10th I'd. USA:Pearson Eduaction Inc

De Voigt, M dan Vervoort, J. 2018. LISTEN to LIVE - our Brain and Music: The Tomatis Listening training and therapy. Belgium: Paragon Publishing

Emy Suryani, S. Y. 2016. Efektifitas Penerapan Lingkungan Persalinan Dengan Terapi Komplementer (Aromaterapi, Terapi Musik, dan Terapi Relaksasi ) Terhadap Penurunan Intensitas Nyeri Persalinan Kala 1 Fase Aktif. Jurnal Kebidanan Dan Kesehatan Tradisional, Volume 1, No 1 hal 199 
Fretham S, Carlson ES, and Georgieff MK.

2011. The role of iron in learning and memory : Advances in nutrition an international review journal.

Hermanto, T.J. 2013. Bersujud Dalam Rahim 2: Mencerdaskan Janin Sejak Dalam Rahim dengan Kombinasi Stimulasi 11-14 Musik Karya Mozart Dan Nutrisi. Surabaya: Global Persada Press .

Hermanto. T.J. 2017. Analisis frekuensi musik Mozart, dengan software cool edit pro 2.0.

Nike Sari Oktavia, S. G. 2013. Perbandingan Efek Musik Klasik Mozart dan Musik Tradisional Gamelan. $M K B$, Volume 45 No. 4.

Pratomo, I. M. 2008. The Temporal and Spectral characteristics of Gamelan Sunda Music. Bandung: Institute of Technology Bandung, Dept. of Engineering Physics - ITB

Shera, C. A. 2015. The Spiral Staircase: Tonotopic Microstructure and Cochlear Tuning. The Journal of Neuroscience, 35(11), 4683-4690.

Sukinah. 2011. Seni Gamlean Jawa Sebagai Alternatif Pendidikan Karakter Bagi Anak Auitis Sekolah Luar Biasa. Fakultas Ilmu Pendidikan Univeritas Negri Yogyakarta, (hal. 134). Yogyakarta.

Supradewi, R. 2010. Otak, Musik Dan Proses Belajar. Buletin Psikologi, Vol 18, NO. 2, $58-68$.

Tony Widyanto, H. T. 2013. Perbandingan Kadar Brain Derived Neurotrophic Factor (BDNF) Serum Darah Tali Pusat Bayi Baru Lahir antara Ibu Hamil yang Mendapat DHA dengan Kombinasi DHA dan 11-14 Karya Mozart Selama Hamil. Majalah Obstetri \& Ginekolog , 109-114.

Widhyatama, S. 2012. Pola Imbal Gamelan

Bali Dalam Kelompok Musisi

Perkusi Cooperland di Kota Semarang. Jurnal Seni Musik, Vol 1. No 1. 